Article

\title{
Study on Worldwide Embodied Impacts of Construction: Analysis of WIOD Release 2016
}

\author{
Yu Mishina ${ }^{1}$, Yosuke Sasaki ${ }^{2}$ and Keizo Yokoyama ${ }^{1, *}$ \\ 1 School of Architecture, Kogakuin University, Tokyo 163-8677, Japan; dm20056@ns.kogakuin.ac.jp \\ $2 \quad$ Niitsugumi Co., Ltd., Nagano 384-1102, Japan; db17147@g.kogakuin.jp \\ * Correspondence: k-yokoyama@cc.kogakuin.ac.jp; Tel.: +81-3-3342-1211
}

Citation: Mishina, Y.; Sasaki, Y.;

Yokoyama, K. Study on Worldwide Embodied Impacts of Construction Analysis of WIOD Release 2016. Energies 2021, 14, 3172. https:// doi.org/10.3390/en14113172

Academic Editors: Francesco Nocera and Chi-Ming Lai

Received: 23 April 2021

Accepted: 26 May 2021

Published: 28 May 2021

Publisher's Note: MDPI stays neutral with regard to jurisdictional claims in published maps and institutional affiliations.

Copyright: (c) 2021 by the authors. Licensee MDPI, Basel, Switzerland. This article is an open access article distributed under the terms and conditions of the Creative Commons Attribution (CC BY) license (https:// creativecommons.org/licenses/by/ $4.0 /)$.

\begin{abstract}
Net-zero-energy buildings (ZEBs) that contribute to making annual energy consumption balances zero are effective measures for reducing greenhouse gas (GHG) emissions in the construction sector. As the application of ZEBs progresses, GHG emissions during the construction of buildings and the manufacturing of materials and products (called construction EG) account for a relatively large proportion of overall emissions. This study aimed to clarify construction EG as a means by which to formulate policies for the reduction of emissions in each country. The construction EGs of 43 countries from 2011 were analyzed. The 56-sector input/output table and $\mathrm{CO}_{2}$ emission data of the 2016 World Input/Output Database, published by the EU, were both used in this analysis. It was found that the construction sector accounted for the highest proportion of total $\mathrm{CO}_{2}$ emissions. Moreover, the fraction of construction EG tended to be higher in developing countries such as China and India, while developed countries tended to contribute a lower fraction of construction EG. Construction EGs were shown to be heavily influenced by the sectors that manufacture "cement", "steel bars and steel frames", and "energy sources". Thus, it is very important to advance technological developments to reduce $\mathrm{CO}_{2}$ emissions within these sectors. The annual variation of construction EGs and $\mathrm{CO}_{2}$ emissions from 2000 to 2014 showed that the construction EGs and total $\mathrm{CO}_{2}$ emissions in developing countries were increasing, whereas emissions from developed countries have been decreasing slightly.
\end{abstract}

Keywords: input/output analysis; World Input/Output Database; embodied GHG emissions; construction EGs; developing countries; cement

\section{Introduction}

\subsection{Background}

It is known that greenhouse gas (GHG) emissions have been a cause of global warming in recent years. At the 21st Conference of the Parties in the United Nations Framework Convention on Climate Change in 2015, the Paris Agreement was adopted, which stipulates a framework for efforts to reduce greenhouse gas emissions beyond 2020. The Paris Agreement stipulates that its goal is to limit the increase in global average temperature to $2.0^{\circ} \mathrm{C}$ or less-preferably to $1.5^{\circ} \mathrm{C}$-compared to preindustrial levels. In order to promote global warming countermeasures in each country, it is important to promote efforts to continuously reduce GHGs [1].

With an annual balance of primary energy consumption of zero, ZEBs (net-zero-energy buildings) and ZEHs (net-zero-energy houses) are effective measures in the construction sector. When ZEBs and ZEHs are achieved in the future, energy consumption and greenhouse gas emissions during building construction and the manufacturing of materials and products will account for a relatively large proportion of overall emissions. Energy consumption and GHG emissions during the construction of buildings and the manufacture of materials and products are known as embodied energy (EE) and embodied GHG emissions (EGs), respectively, and both are collectively called the embodied impact or EEGs [2]. 
In order to promote EEG reduction, it is important for each country to formulate measures that are considered to be effective.

The purpose of this study was to analyze the EGs related to construction (hereafter referred to as "construction EGs") in various countries and to clarify their components of construction EG and the differences between countries. The results of this research should provide valuable resources for effective measures to reduce construction EG for policymakers and engineers. For this analysis, the 2016 release of the World Input/Output Database (hereafter referred to as "WIOD (2016)") published by the European Union (EU) was used [3]. The WIOD (2016) is suitable for a comparison of countries because the input/output (IO) tables for 43 countries in 56 sectors are created with the same specifications.

Prior to its most recent iteration, the World Input-Output Database 2013 Release (WIOD (2013)) was published. WIOD (2013) provides IO tables for 40 countries in 35 sectors. An analysis using the WIOD (2013) was conducted by Yokoyama [4] in Japanese. However, an analysis using the WIOD (2016), which includes increased number of sectors, as well as target countries, allows for a more precise analysis. Moreover, as the WIOD (2016) provides IO tables from 2000 to 2014, the latest trends can be understood.

\subsection{Embodied Impact}

The research on EEG was conducted by Annex 57, one of the research projects in the "EBC" (Energy in Buildings and Communities) of the IEA (International Energy Agency) [5].

In Annex 57, primary energy consumption intensity is classified as follows according to the type of energy source [2]:

1. Pef: Primary energy from fossil fuels only;

2. Penr: Primary energy from fossil fuels and nuclear power;

3. Pet: Total primary energy from fossil fuels, nuclear power, and renewable energy.

In addition, four types of EEG boundaries are defined, as shown in Figure 1; A1 to C4 are called "Cradle-to-Grave", A1 to A3 are called "Cradle-to-Gate", A1 to A4 are called "Cradle-to-Site", and A1 to A5 are called "Cradle-to-Handover".

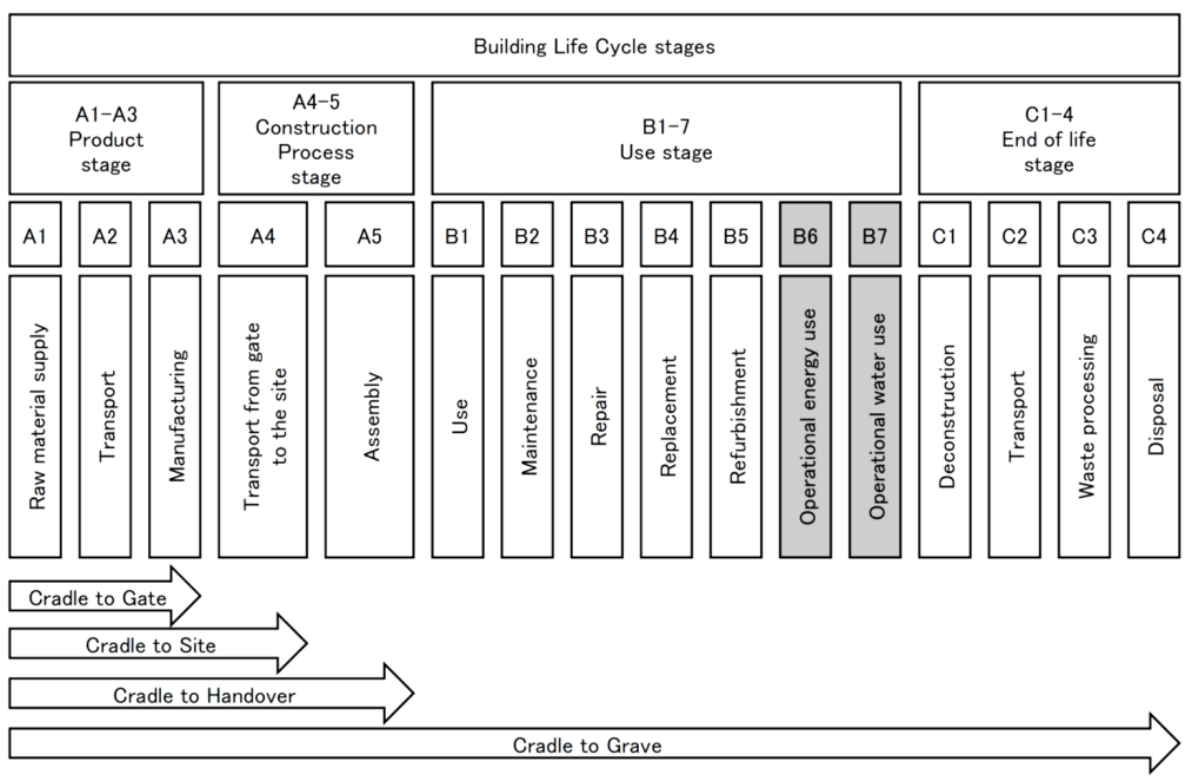

Figure 1. Proposed model for system boundaries [2].

\subsection{Previous Research Using WIOD}

Several studies on environmental load using the WIOD have been conducted. Cruz et al. [6] assessed the economy-ecology-environment interactions and $\mathrm{CO}_{2}$ emissions for EU countries. Zhang et al. [7] also analyzed the $\mathrm{CO}_{2}$ and energy flows associated with trade in 
BRICS countries. As a result, it was found that the amount of $\mathrm{CO}_{2}$ transferred to countries other than those in BRICS was large. In addition, it has been shown that China has a large impact on the world due to its sizeable economy. Jiborn et al. [8] used the WIOD (2016) to compare production-based, consumption-based, and technology-adjusted $\mathrm{CO}_{2}$ emissions for 44 countries and country groups from 2000 to 2014 . The results showed that emissions were declining on a production and consumption basis in 20 European Union (EU) countries and the United States (US). The significant increase in global emissions that occurred during this period was due to increased consumption in China and developing countries. In addition, Fan et al. [9] used the WIOD (2013) to compare consumption-based (CBA) and production-based (PBA) $\mathrm{CO}_{2}$ emissions in 14 countries. As a result, it was shown that countries could be classified into four categories according to the difference in the ratio of $\mathrm{CBA}$ to $\mathrm{PBA}$ emissions. It was also confirmed that $\mathrm{CBA} \mathrm{CO}_{2}$ emissions have a positive correlation with gross domestic product (GDP) per capita.

These studies were for all industries. There were not many studies focusing on the construction sector, except for the following.

Zhang et al. [10] used the WIOD (2013) to study of the global impact of the construction sector by means of a hypothetical extraction method (HEM), and they evaluated the impact of backward and forward $\mathrm{CO}_{2}$ emission linkages in the construction sector. On the other hand, Yokoyama [4] used the WIOD (2013) to analyze the construction EGs of each country. In this study, $\mathrm{CO}_{2}$ emission intensity was calculated for 35 sectors in 40 countries, and the construction EGs of each country and the composition of each sector's input to construction were analyzed. The fraction of construction EG was found to be large in developing countries such as China and India, but small in developed countries. In addition, the annual change in construction EGs from 1995 to 2009 showed that the growth in developing countries was large, while that in developed countries was small.

In our study, construction EGs were analyzed using the latest version of the WIOD (2016) instead of the 2013 version described above.

\section{Materials and Methods}

\subsection{Overview of the WIOD (2016)}

The WIOD (2016) consists of the world IO table (WIOT), which is a collection of IO tables for all countries, IO tables for each country (national IO tables (NIOTs)), and environmental accounts [11].

Figure 2 shows the framework of the NIOTs. In NIOTs, items are divided into domestic and imported products, and prices are shown in USD. A conversion table with the local currency is provided for the list price.

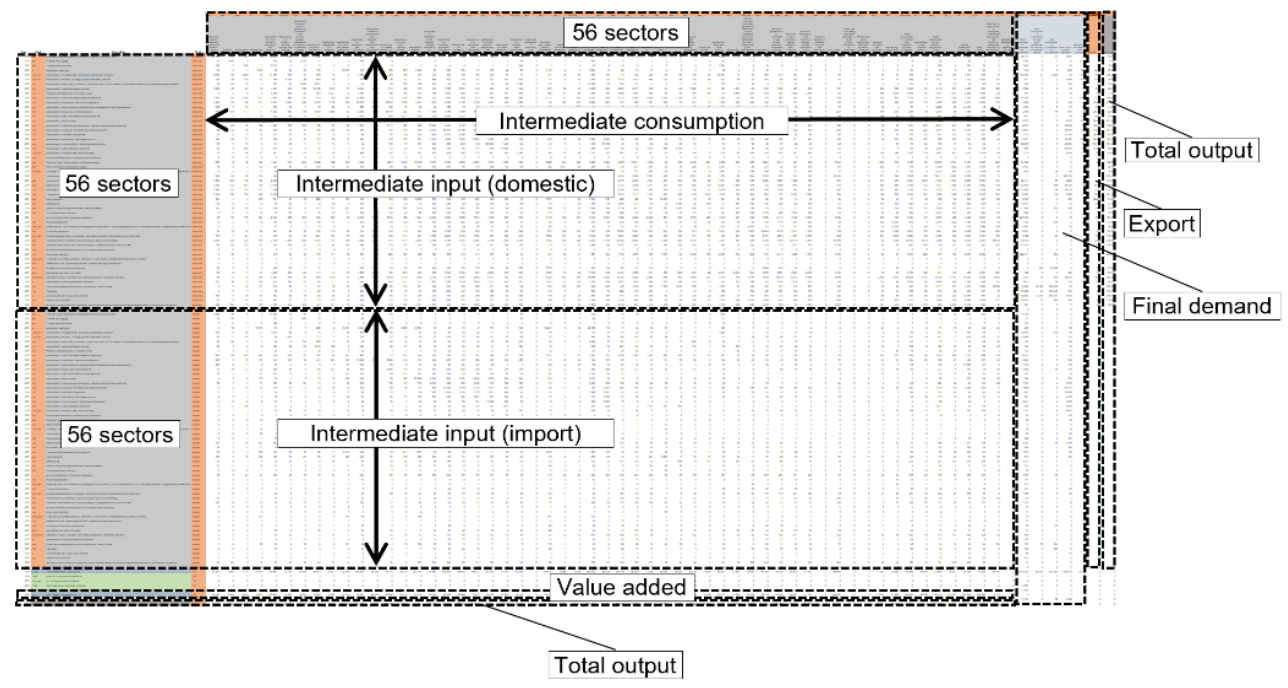

Figure 2. National input/output (IO) table (NIOT) framework. 
The WIOD (2016) offers NIOTs of 56 sectors in 43 countries from 2000 to 2014. Table 1 shows the names of the 56 sectors in the NIOTs. In the figures that follow, sector names are represented by the numbers shown in Table 1 .

Table 1. List of sectors [3].

\begin{tabular}{|c|c|c|}
\hline No. & Item & Sectors \\
\hline 1 & A01 & Crop and animal production, hunting and related service activities \\
\hline 2 & A02 & Forestry and logging \\
\hline 3 & A03 & Fishing and aquaculture \\
\hline 4 & $\mathrm{~B}$ & Mining and quarrying \\
\hline 5 & $\mathrm{C} 10-\mathrm{C} 12$ & Manufacture of food products, beverages and tobacco products \\
\hline 6 & $\mathrm{C} 13-\mathrm{C} 15$ & Manufacture of textiles, wearing apparel and leather products \\
\hline 7 & C16 & $\begin{array}{c}\text { Manufacture of wood and of products of wood and cork, except furniture; manufacture of articles of straw and } \\
\text { plaiting materials }\end{array}$ \\
\hline 8 & C17 & Manufacture of paper and paper products \\
\hline 9 & $\mathrm{C} 18$ & Printing and reproduction of recorded media \\
\hline 10 & C19 & Manufacture of coke and refined petroleum products \\
\hline 11 & $\mathrm{C} 20$ & Manufacture of chemicals and chemical products \\
\hline 12 & $\mathrm{C} 21$ & Manufacture of basic pharmaceutical products and pharmaceutical preparations \\
\hline 13 & $\mathrm{C} 22$ & Manufacture of rubber and plastic products \\
\hline 14 & $\mathrm{C} 23$ & Manufacture of other non-metallic mineral products \\
\hline 15 & $\mathrm{C} 24$ & Manufacture of basic metals \\
\hline 16 & $\mathrm{C} 25$ & Manufacture of fabricated metal products, except machinery and equipment \\
\hline 17 & $\mathrm{C} 26$ & Manufacture of computer, electronic and optical products \\
\hline 18 & $\mathrm{C} 27$ & Manufacture of electrical equipment \\
\hline 19 & $\mathrm{C} 28$ & Manufacture of machinery and equipment n.e.c. \\
\hline 20 & C29 & Manufacture of motor vehicles, trailers and semi-trailers \\
\hline 21 & $\mathrm{C} 30$ & Manufacture of other transport equipment \\
\hline 22 & C31-C32 & Manufacture of furniture; other manufacturing \\
\hline 23 & C33 & Repair and installation of machinery and equipment \\
\hline 24 & D35 & Electricity, gas, steam and air conditioning supply \\
\hline 25 & E36 & Water collection, treatment and supply \\
\hline 26 & E37-E39 & $\begin{array}{c}\text { Sewerage; waste collection, treatment and disposal activities; materials recovery; remediation activities and other } \\
\text { waste management services }\end{array}$ \\
\hline 27 & $\mathrm{~F}$ & Construction \\
\hline 28 & G45 & Wholesale and retail trade and repair of motor vehicles and motorcycles \\
\hline 29 & G46 & Wholesale trade, except of motor vehicles and motorcycles \\
\hline 30 & G47 & Retail trade, except of motor vehicles and motorcycles \\
\hline 31 & $\mathrm{H} 49$ & Land transport and transport via pipelines \\
\hline 32 & $\mathrm{H} 50$ & Water transport \\
\hline 33 & H51 & Air transport \\
\hline 34 & $\mathrm{H} 52$ & Warehousing and support activities for transportation \\
\hline 35 & H53 & Postal and courier activities \\
\hline 36 & I & Accommodation and food service activities \\
\hline 37 & $\mathrm{~J} 58$ & Publishing activities \\
\hline 38 & J59-J60 & $\begin{array}{c}\text { Motion picture, video and television programme production, sound recording and music publishing activities; } \\
\text { programming and broadcasting activities }\end{array}$ \\
\hline 39 & J61 & Telecommunications \\
\hline 40 & $\mathrm{~J} 62-\mathrm{J} 63$ & Computer programming, consultancy and related activities; information service activities \\
\hline 41 & K64 & Financial service activities, except insurance and pension funding \\
\hline 42 & K65 & Insurance, reinsurance and pension funding, except compulsory social security \\
\hline 43 & K66 & Activities auxiliary to financial services and insurance activities \\
\hline 44 & L68 & Real estate activities \\
\hline 45 & M69-M70 & Legal and accounting activities; activities of head offices; management consultancy activities \\
\hline 46 & M71 & Architectural and engineering activities; technical testing and analysis \\
\hline 47 & M72 & Scientific research and development \\
\hline 48 & M73 & Advertising and market research \\
\hline 49 & M74-M75 & Other professional, scientific and technical activities; veterinary activities \\
\hline 50 & $\mathrm{~N}$ & Administrative and support service activities \\
\hline 51 & O84 & Public administration and defence; compulsory social security \\
\hline 52 & P85 & Education \\
\hline 53 & $\mathrm{Q}$ & Human health and social work activities \\
\hline 54 & $\mathrm{R}-\mathrm{S}$ & Other service activities \\
\hline 55 & $\mathrm{~T}$ & $\begin{array}{c}\text { Activities of households as employers; undifferentiated goods- and services-producing activities of households for } \\
\text { own use }\end{array}$ \\
\hline 56 & $\mathrm{U}$ & Activities of extraterritorial organizations and bodies \\
\hline
\end{tabular}




\subsection{Overview of Target Countries}

Table 2 shows gross national income (GNI) per capita according to the World Bank [12,13] and energy-derived $\mathrm{CO}_{2}$ emissions according to the International Energy Agency (IEA) [14] for the 43 countries. The total energy-derived $\mathrm{CO}_{2}$ emissions of the 43 countries analyzed account for approximately $80 \%$ of the world's total emissions.

Table 2. List of countries, along with their gross national income (GNI) [12,13] and $\mathrm{CO}_{2}$ emissions [14] (2011).

\begin{tabular}{|c|c|c|c|c|c|}
\hline No. & Country Code & GNI (Billion USD) & GNI per Capita (USD) & $\mathrm{CO}_{2}$ Emission $\left(\times 10^{6} \mathrm{t}-\mathrm{CO}_{2}\right)$ & Ratio (\%) \\
\hline 1 & $\mathrm{CHN}$ & 7481.12 & 5565.77 & 8570.93 & 27.3 \\
\hline 2 & USA & $15,832.21$ & $50,816.43$ & 5128.18 & 16.3 \\
\hline 3 & IND & 1807.02 & 1445.28 & 1667.76 & 5.3 \\
\hline 4 & RUS & 1985.53 & $13,888.60$ & 1607.95 & 5.1 \\
\hline 5 & JPN & 6331.88 & $49,532.44$ & 1183.49 & 3.8 \\
\hline 6 & DEU & 3840.29 & $47,839.23$ & 731.22 & 2.3 \\
\hline 7 & KOR & 1260.98 & $25,251.61$ & 573.76 & 1.8 \\
\hline 8 & CAN & 1758.97 & $51,223.17$ & 541.16 & 1.7 \\
\hline 9 & MEX & 1161.74 & $10,041.39$ & 456.46 & 1.5 \\
\hline 10 & GBR & 2669.89 & $42,205.76$ & 439.18 & 1.4 \\
\hline 11 & BRA & 2548.97 & $12,905.24$ & 391.09 & 1.2 \\
\hline 12 & IDN & 868.24 & 3542.15 & 390.32 & 1.2 \\
\hline 13 & ITA & 2286.19 & $38,501.44$ & 384.11 & 1.2 \\
\hline 14 & AUS & 1340.59 & $60,008.33$ & 382.11 & 1.2 \\
\hline 15 & FRA & 2937.48 & $44,954.91$ & 322.27 & 1.0 \\
\hline 16 & POL & 511.68 & $13,442.95$ & 303.19 & 1.0 \\
\hline 17 & TUR & 825.27 & $11,236.81$ & 287.20 & 0.9 \\
\hline 18 & ESP & 1452.68 & $31,078.16$ & 264.87 & 0.8 \\
\hline 19 & TWN & - & - & 255.46 & 0.8 \\
\hline 20 & NLD & 916.73 & $54,917.08$ & 158.41 & 0.5 \\
\hline 21 & $\mathrm{CZE}$ & 210.69 & $20,072.81$ & 109.32 & 0.3 \\
\hline 22 & BEL & 523.48 & $47,424.28$ & 92.81 & 0.3 \\
\hline 23 & GRC & 279.94 & $25,208.71$ & 82.12 & 0.3 \\
\hline 24 & ROU & 181.11 & 8989.08 & 80.86 & 0.3 \\
\hline 25 & AUT & 432.57 & $51,548.18$ & 67.01 & 0.2 \\
\hline 26 & FIN & 276.30 & $51,277.56$ & 54.56 & 0.2 \\
\hline 27 & BGR & 55.56 & 7560.80 & 49.17 & 0.2 \\
\hline 28 & PRT & 240.83 & $22,811.21$ & 47.05 & 0.1 \\
\hline 29 & HUN & 134.32 & $13,470.15$ & 46.34 & 0.1 \\
\hline 30 & SWE & 584.48 & $61,855.31$ & 42.35 & 0.1 \\
\hline 31 & DNK & 351.26 & $63,055.84$ & 42.06 & 0.1 \\
\hline 32 & $\mathrm{CHE}$ & 707.65 & $89,435.44$ & 39.23 & 0.1 \\
\hline 33 & NOR & 503.52 & $101,657.40$ & 36.22 & 0.1 \\
\hline 34 & IRL & 192.53 & $42,036.42$ & 35.38 & 0.1 \\
\hline 35 & SVK & 95.59 & $17,706.25$ & 32.85 & 0.1 \\
\hline 36 & HRV & 60.31 & $14,089.97$ & 17.95 & 0.1 \\
\hline 37 & EST & 22.21 & $16,732.11$ & 17.63 & 0.1 \\
\hline 38 & SVN & 50.82 & $24,754.46$ & 15.43 & 0.0 \\
\hline 39 & LTU & 42.19 & $13,933.23$ & 11.53 & 0.0 \\
\hline 40 & LUX & 41.43 & $79,927.99$ & 10.51 & 0.0 \\
\hline 41 & LVA & 28.46 & $13,818.00$ & 7.34 & 0.0 \\
\hline 42 & CYP & 28.29 & $25,151.79$ & 7.00 & 0.0 \\
\hline 43 & MLT & 9.21 & $22,117.24$ & 2.57 & 0.0 \\
\hline \multicolumn{4}{|c|}{ Other countries } & 6406.16 & 20.4 \\
\hline \multicolumn{4}{|c|}{ All of the world } & $31,392.58$ & 100.0 \\
\hline
\end{tabular}

USD represents current prices in United States (US) dollars. 


\subsection{Calculation of $\mathrm{CO}_{2}$ Emission Intensities}

\subsubsection{Summary of Calculation}

The intensities of $\mathrm{CO}_{2}$ emissions were calculated using the NIOTs and environmental accounts from the WIOD (2016).

\subsubsection{Calculation of $\mathrm{CO}_{2}$ Emission Intensities}

As shown in Figure 2, the NIOTs distinguished between domestic products and imported products. Since this analysis targeted domestic $\mathrm{CO}_{2}$ emissions in each country and did not consider overseas spillover effects, the IO tables of domestic goods were used for this analysis. The calculation procedure according to Yokoyama [4] is described below.

The input coefficient $a_{\mathrm{ij}}^{\mathrm{d}}$ for domestic goods is expressed by the following equation [15]:

$$
a_{i j}^{d}=\frac{X_{i j}^{d}}{X_{i}}
$$

where $X_{i j}^{d}$ is the domestic product from sector $j$ to sector $i$ (million USD/year), $X_{i}$ is the gross domestic product (total output) (million USD/year), and $i$ (row) and $j$ (column) are sector numbers.

The gross domestic product vector $\mathbf{X}$ is expressed by the following equation [15]:

$$
\mathbf{X}=\mathbf{A}^{\mathrm{d}} \mathbf{X}+\left(\mathbf{F}^{\mathrm{d}}+\mathbf{F}^{\mathrm{E}}\right),
$$

Solving Equation (2) for $\mathbf{X}$ gives the following equation [15]:

$$
\mathbf{X}=\left(\mathbf{I}-\mathbf{A}^{\mathrm{d}}\right)^{-1} \times\left(\mathbf{F}^{\mathrm{d}}+\mathbf{F}^{\mathrm{E}}\right),
$$

where $\mathbf{X}$ is the gross domestic product vector, with $\mathbf{X}_{\mathrm{i}}$ as an element (million USD/year); $\left(\mathbf{I}-\mathbf{A}^{\mathrm{d}}\right)^{-1}$ is the Leontief inverse matrix; I is the unit matrix; $\mathbf{A}^{\mathrm{d}}$ is the activity matrix of the gross domestic product with $\mathrm{a}_{\mathrm{ij}}^{\mathrm{d}}$ as an element, $\mathrm{F}^{\mathrm{d}}$ is the final demand vector of domestic goods (million USD/year); and $\mathrm{F}^{\mathrm{E}}$ is the export vector (exports) (million USD/year).

$\mathrm{CO}_{2}$ emission intensity $\left(\mathbf{I C O}_{2}\right)$, including the spillover effect is calculated by multiplying the direct $\mathrm{CO}_{2}$ emissions per million USD of the producer price by the Leontief inverse matrix of Equation (3), as shown in Equation (4):

$$
\mathrm{ICO}_{2}=\mathrm{CO}_{2}\left(\mathrm{I}-\mathrm{A}^{\mathrm{d}}\right)^{-1},
$$

where $\mathrm{ICO}_{2}$ is the $\mathrm{CO}_{2}$ emission basic unit vector, with spillover effects per manufacturer price of 1 million USD in each industry ( $\mathrm{kg}-\mathrm{CO}_{2} /$ million USD), and $\mathrm{CO}_{2}$ is the direct $\mathrm{CO}_{2}$ emission row vector per manufacturer price of 1 million USD in each industry (kg$\mathrm{CO}_{2}$ /million USD).

Direct $\mathrm{CO}_{2}$ emissions $\left(\mathrm{CO}_{2 \mathrm{i}}\right)$ per million USD of producer price in Equation (4) are expressed as follows on the basis of emission data:

$$
\mathrm{CO}_{2 \mathrm{i}}=\frac{\mathrm{SCO}_{2 \mathrm{i}}}{\mathrm{X}_{\mathrm{i}}}
$$

where $\mathrm{CO}_{2 \mathrm{i}}$ represents the direct $\mathrm{CO}_{2}$ emissions per manufacturer price of 1 million USD in sector $\mathrm{i}\left(\mathrm{kg}-\mathrm{CO}_{2} /\right.$ million USD), $\mathrm{X}_{\mathrm{i}}$ is the gross domestic product value in sector $\mathrm{i}$ (million $\mathrm{USD} /$ year), and $\mathrm{SCO}_{2 \mathrm{i}}$ represents the total $\mathrm{CO}_{2}$ emissions in sector $\mathrm{i}\left(\mathrm{kg}-\mathrm{CO}_{2} /\right.$ year).

Therefore, the induced $\mathrm{CO}_{2}$ emissions $\left(\mathrm{SCO}_{2 \mathrm{i}}\right)$ due to the final demand for each sector are expressed by the following equation from Equations (3)-(5):

$$
\mathrm{SCO}_{2 \mathrm{i}}=\mathrm{ICO}_{2 \mathrm{i}} \times \mathrm{F}_{\mathrm{i}}
$$


where $\mathrm{SCO}_{2 \mathrm{i}}$ represents the induced $\mathrm{CO}_{2}$ emissions from the final demand of sector $\mathrm{i}$ ( $\mathrm{kg}-\mathrm{CO}_{2}$ /year), $\mathrm{ICO}_{2 \mathrm{i}}$ is the $\mathrm{CO}_{2}$ emission intensity of sector $\mathrm{i}\left(\mathrm{kg}-\mathrm{CO}_{2} /\right.$ million USD), and $\mathrm{F}_{\mathrm{i}}$ is the final demand of sector $\mathrm{i}$ (million USD/year).

\section{Results}

\section{1. $\mathrm{CO}_{2}$ Emission Intensity and $\mathrm{CO}_{2}$ Emissions by Sector}

From the abovementioned step in Section 2.3.2, $2011 \mathrm{CO}_{2}$ emission intensities by sector, as well as $\mathrm{CO}_{2}$ emissions by sector and their ratios, were calculated for 43 countries. Table 3 shows the calculation results for Japan.

Table 3. $\mathrm{CO}_{2}$ emission intensities (JPN, 2011).

\begin{tabular}{|c|c|c|c|c|}
\hline No. & Sectors & $\begin{array}{c}\mathrm{CO}_{2} \text { Emission } \\
\text { Intensity } \\
\left(\mathrm{t}-\mathrm{CO}_{2} / \text { Million USD) }\right.\end{array}$ & $\begin{array}{l}\mathrm{CO}_{2} \text { Emission by } \\
\text { Sector } \\
\left(\mathrm{t}-\mathrm{CO}_{2}\right)\end{array}$ & $\begin{array}{c}\text { Ratio } \\
(\%)\end{array}$ \\
\hline 1 & $\begin{array}{c}\text { Crop and animal production, hunting and related } \\
\text { service activities }\end{array}$ & 135 & $4,919,168$ & 0.44 \\
\hline 2 & Forestry and logging & 107 & 116,275 & 0.01 \\
\hline 3 & Fishing and aquaculture & 213 & 541,109 & 0.05 \\
\hline 4 & Mining and quarrying & 651 & 444,719 & 0.04 \\
\hline 5 & $\begin{array}{c}\text { Manufacture of food products, beverages and } \\
\text { tobacco products }\end{array}$ & 157 & $40,997,531$ & 3.67 \\
\hline 6 & $\begin{array}{c}\text { Manufacture of textiles, wearing apparel and } \\
\text { leather products }\end{array}$ & 268 & $4,162,533$ & 0.37 \\
\hline 7 & $\begin{array}{c}\text { Manufacture of wood and of products of wood and cork, } \\
\text { except furniture; manufacture of articles of straw and } \\
\text { plaiting materials }\end{array}$ & 135 & 32,947 & 0.00 \\
\hline 8 & Manufacture of paper and paper products & 393 & $3,158,788$ & 0.28 \\
\hline 9 & Printing and reproduction of recorded media & 152 & 207,932 & 0.02 \\
\hline 10 & Manufacture of coke and refined petroleum products & 269 & $21,557,835$ & 1.93 \\
\hline 11 & Manufacture of chemicals and chemical products & 497 & $42,722,640$ & 3.83 \\
\hline 12 & $\begin{array}{c}\text { Manufacture of basic pharmaceutical products and } \\
\text { pharmaceutical preparations }\end{array}$ & 131 & $1,406,607$ & 0.13 \\
\hline 13 & Manufacture of rubber and plastic products & 274 & $9,628,872$ & 0.86 \\
\hline 14 & Manufacture of other non-metallic mineral products & 982 & $14,135,752$ & 1.27 \\
\hline 15 & Manufacture of basic metals & 895 & $70,290,173$ & 6.30 \\
\hline 16 & $\begin{array}{c}\text { Manufacture of fabricated metal products, except } \\
\text { machinery and equipment }\end{array}$ & 323 & $26,602,346$ & 2.38 \\
\hline 17 & $\begin{array}{l}\text { Manufacture of computer, electronic and } \\
\text { optical products }\end{array}$ & 178 & $31,547,894$ & 2.83 \\
\hline 18 & Manufacture of electrical equipment & 248 & $30,793,610$ & 2.76 \\
\hline 19 & Manufacture of machinery and equipment n.e.c. & 198 & $34,171,918$ & 3.06 \\
\hline 20 & Manufacture of motor vehicles, trailers and semi-trailers & 211 & $50,125,125$ & 4.49 \\
\hline 21 & Manufacture of other transport equipment & 230 & $11,692,167$ & 1.05 \\
\hline 22 & Manufacture of furniture; other manufacturing & 248 & $5,639,812$ & 0.51 \\
\hline 23 & Repair and installation of machinery and equipment & 0 & 0 & 0.00 \\
\hline 24 & Electricity, gas, steam and air conditioning supply & 2009 & $151,250,059$ & 13.55 \\
\hline 25 & Water collection, treatment and supply & 91 & $1,100,709$ & 0.10 \\
\hline 26 & $\begin{array}{c}\text { Sewerage; waste collection, treatment and disposal } \\
\text { activities; materials recovery; remediation activities and } \\
\text { other waste management services }\end{array}$ & 398 & 770,038 & 0.07 \\
\hline 27 & Construction & 167 & $104,337,632$ & 9.35 \\
\hline 28 & $\begin{array}{l}\text { Wholesale and retail trade and repair of motor vehicles } \\
\text { and motorcycles }\end{array}$ & 137 & $5,022,185$ & 0.45 \\
\hline 29 & $\begin{array}{c}\text { Wholesale trade, except of motor vehicles and } \\
\text { motorcycles }\end{array}$ & 68 & $22,968,291$ & 2.06 \\
\hline 30 & Retail trade, except of motor vehicles and motorcycles & 142 & $48,340,521$ & 4.33 \\
\hline 31 & Land transport and transport via pipelines & 228 & $29,826,951$ & 2.67 \\
\hline 32 & Water transport & 1569 & $58,658,307$ & 5.26 \\
\hline 33 & Air transport & 409 & $10,734,638$ & 0.96 \\
\hline
\end{tabular}


Table 3. Cont.

\begin{tabular}{|c|c|c|c|c|}
\hline No. & Sectors & $\begin{array}{c}\mathrm{CO}_{2} \text { Emission } \\
\text { Intensity } \\
\left(\mathrm{t}-\mathrm{CO}_{2} / \text { Million USD) }\right.\end{array}$ & $\begin{array}{l}\mathrm{CO}_{2} \text { Emission by } \\
\text { Sector } \\
\left(\mathrm{t}-\mathrm{CO}_{2}\right)\end{array}$ & $\begin{array}{c}\text { Ratio } \\
(\%)\end{array}$ \\
\hline 34 & Warehousing and support activities for transportation & 142 & $4,134,704$ & 0.37 \\
\hline 35 & Postal and courier activities & 120 & 334,482 & 0.03 \\
\hline 36 & Accommodation and food service activities & 159 & $43,740,026$ & 3.92 \\
\hline 37 & Publishing activities & 131 & $1,275,492$ & 0.11 \\
\hline 38 & $\begin{array}{l}\text { Motion picture, video and television programme } \\
\text { production, sound recording and music publishing } \\
\text { activities; programming and broadcasting activities }\end{array}$ & 87 & $1,028,811$ & 0.09 \\
\hline 39 & Telecommunications & 65 & $6,364,287$ & 0.57 \\
\hline 40 & $\begin{array}{l}\text { Computer programming, consultancy and related } \\
\text { activities; information service activities }\end{array}$ & 67 & $6,104,915$ & 0.55 \\
\hline 41 & $\begin{array}{l}\text { Financial service activities, except insurance and } \\
\text { pension funding }\end{array}$ & 42 & $1,658,484$ & 0.15 \\
\hline 42 & $\begin{array}{l}\text { Insurance, reinsurance and pension funding, except } \\
\text { compulsory social security }\end{array}$ & 64 & $6,951,031$ & 0.62 \\
\hline 43 & $\begin{array}{c}\text { Activities auxiliary to financial services and } \\
\text { insurance activities }\end{array}$ & 0 & 0 & 0.00 \\
\hline 44 & Real estate activities & 19 & $15,207,451$ & 1.36 \\
\hline 45 & $\begin{array}{l}\text { Legal and accounting activities; activities of head offices; } \\
\text { management consultancy activities }\end{array}$ & 0 & 0 & 0.00 \\
\hline 46 & $\begin{array}{l}\text { Architectural and engineering activities; technical testing } \\
\text { and analysis }\end{array}$ & 0 & 0 & 0.00 \\
\hline 47 & Scientific research and development & 225 & $4,224,921$ & 0.38 \\
\hline 48 & Advertising and market research & 105 & 139,685 & 0.01 \\
\hline 49 & $\begin{array}{c}\text { Other professional, scientific and technical activities; } \\
\text { veterinary activities }\end{array}$ & 51 & $2,537,592$ & 0.23 \\
\hline 50 & Administrative and support service activities & 47 & 409,931 & 0.04 \\
\hline 51 & $\begin{array}{l}\text { Public administration and defence; compulsory } \\
\text { social security }\end{array}$ & 106 & $74,165,062$ & 6.65 \\
\hline 52 & Education & 75 & $17,767,389$ & 1.59 \\
\hline 53 & Human health and social work activities & 93 & $59,202,423$ & 5.31 \\
\hline 54 & Other service activities & 130 & $32,583,913$ & 2.92 \\
\hline 55 & $\begin{array}{l}\text { Activities of households as employers; undifferentiated } \\
\text { goods- and services-producing activities of households } \\
\text { for own use }\end{array}$ & 113 & 144,863 & 0.01 \\
\hline 56 & Activities of extraterritorial organizations and bodies & 0 & 0 & 0.00 \\
\hline & Total & & $1,115,880,548$ & 100.00 \\
\hline
\end{tabular}

\subsection{Impact by Sectors}

Figure 3 shows the results of $\mathrm{CO}_{2}$ emissions of 56 sectors in 43 countries for each sector, as well as the ratio of each sector to total $\mathrm{CO}_{2}$ emissions (56 sectors and a total of 43 countries). The sector with the highest share of total $\mathrm{CO}_{2}$ emissions was "27: construction $(19 \%)^{\prime \prime}$, followed by " 24 : electricity, gas, steam, and air-conditioning supply $(12 \%)$ ".

Therefore, it was confirmed that a reduction in emissions in the construction sector would be effective in reducing overall $\mathrm{CO}_{2}$ emissions. 


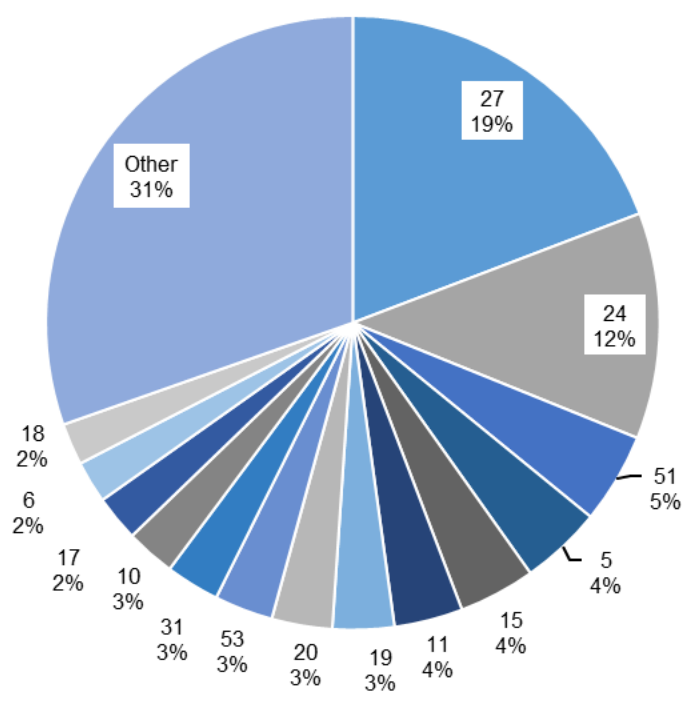

Figure 3. $\mathrm{CO}_{2}$ emissions of each sector.

\subsection{Construction EGs}

Figure 4 shows the relationship between the fraction of construction EG in each country and the fraction of global $\mathrm{CO}_{2}$ emissions. The vertical axis is the fraction of construction $\mathrm{EG}$ and the horizontal axis is the fraction of global $\mathrm{CO}_{2}$ emissions. The magnitude of the absolute value of construction EG is indicated by the size of the area of the quadrangle. The fraction of construction EG refers to the fraction of $\mathrm{CO}_{2}$ emissions of "27: construction" to domestic emissions, and it is the value shown in the "ratio" column in Table 3.

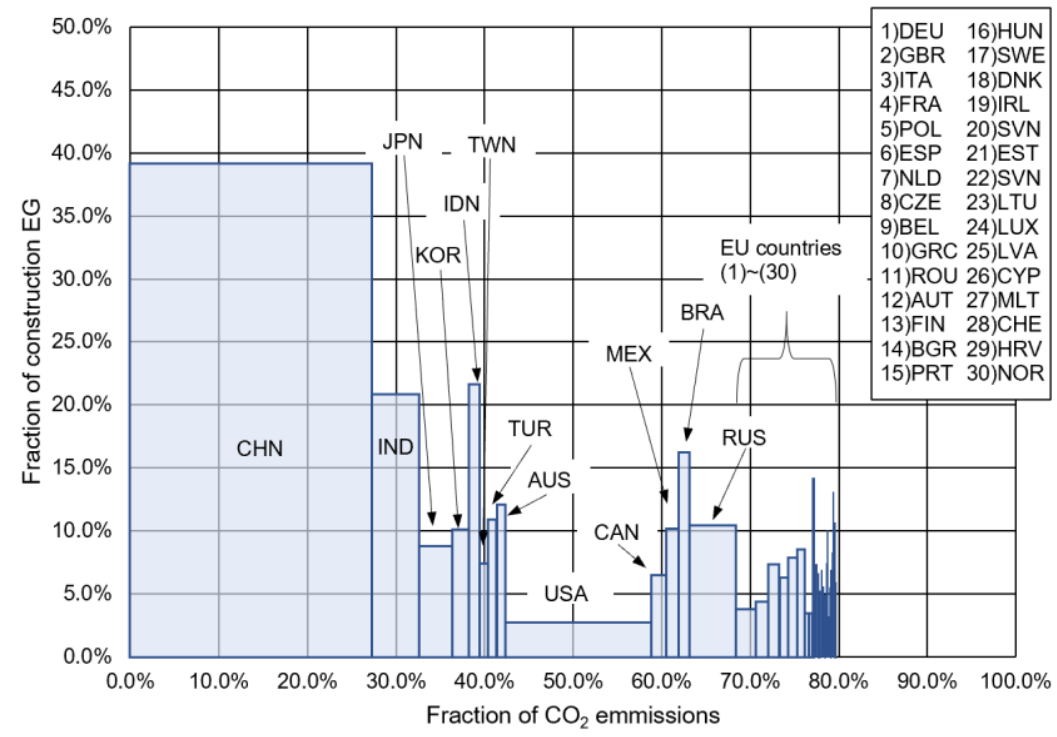

Figure 4. Fraction of construction EG and total $\mathrm{CO}_{2}$ emissions.

In China, as the fractions of both construction EG and the fraction of $\mathrm{CO}_{2}$ emissions are large, the country's construction EG is the largest globally. China is followed by India, Russia, the United States, and Japan, in that order. Accordingly, it should be considered that activities to reduce $\mathrm{CO}_{2}$ emissions related to construction in China and India can contribute to a global reduction in $\mathrm{CO}_{2}$ emissions.

Figure 5 shows the relationship between GNI per capita and the fraction of construction EG. The income of 43 countries was classified by referring to the standard of income classification by GNI per capita published by the World Bank in 2012 [16]. 


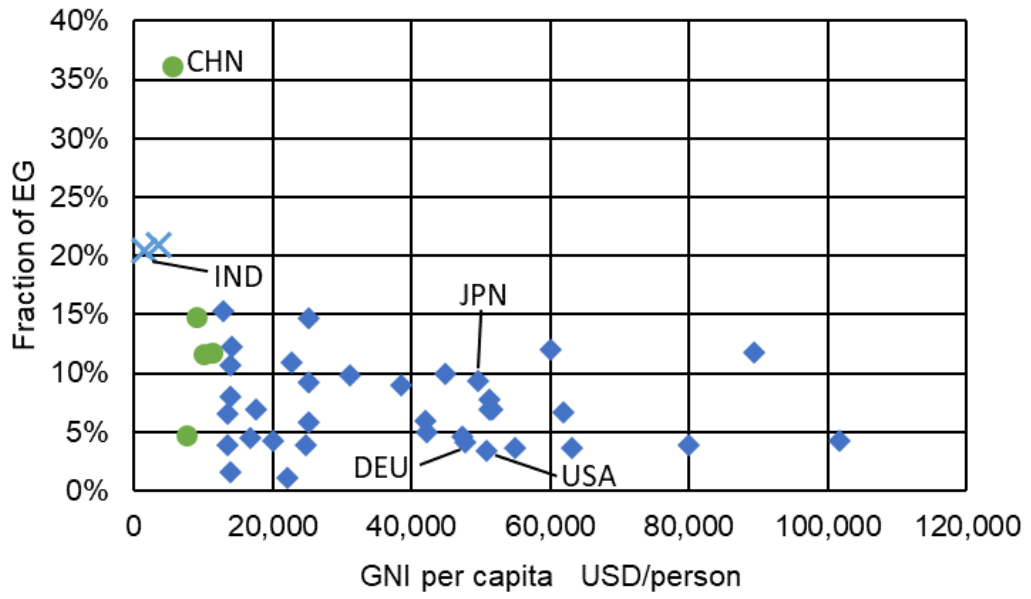

High income $(\$ 12,476$ or more $)$
- Upper lower income $(\$ 4036$ to $\$ 12,475)$
$\times$ Lower middle income $(\$ 1026$ to $\$ 4035)$

Figure 5. Relationship between GNI per capita and fraction of construction EGs (2011).

According to Figure 5, construction EG tends to be higher in developing countries such as China and India.

\subsection{Composition of Construction EGs}

It was found that construction EGs account for a large part of $\mathrm{CO}_{2}$ emissions. In order to reduce construction EGs, an analysis of the sectors contributing to construction EGs is required. The main materials for construction and the corresponding WIOD (2016) sector names are shown in Figure 6.

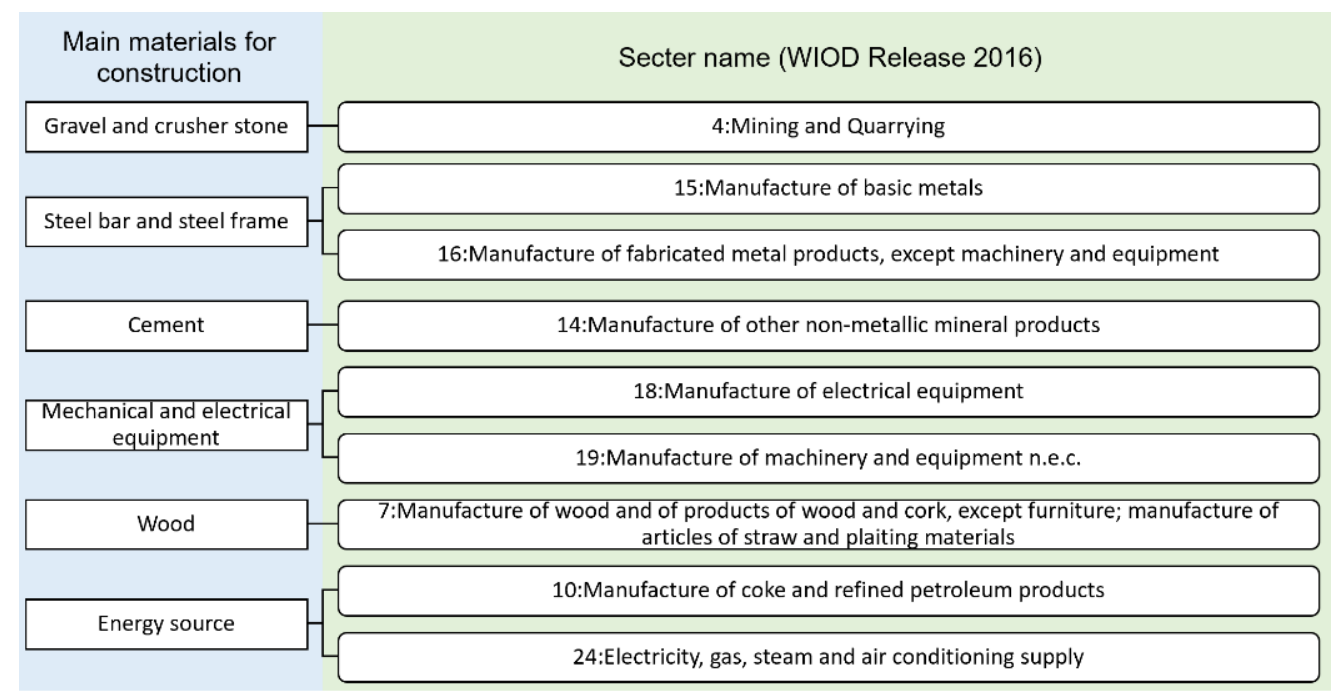

Figure 6. Sector-specific construction materials.

Figure 7 shows the calculation results for $\mathrm{CO}_{2}$ emissions by the construction sector in Japan, the United States, China, India, and Germany, according to Equation (6). However, $\mathrm{Fi}$ is the amount of $\mathrm{i}$-sector which has been invested in the construction sector. 


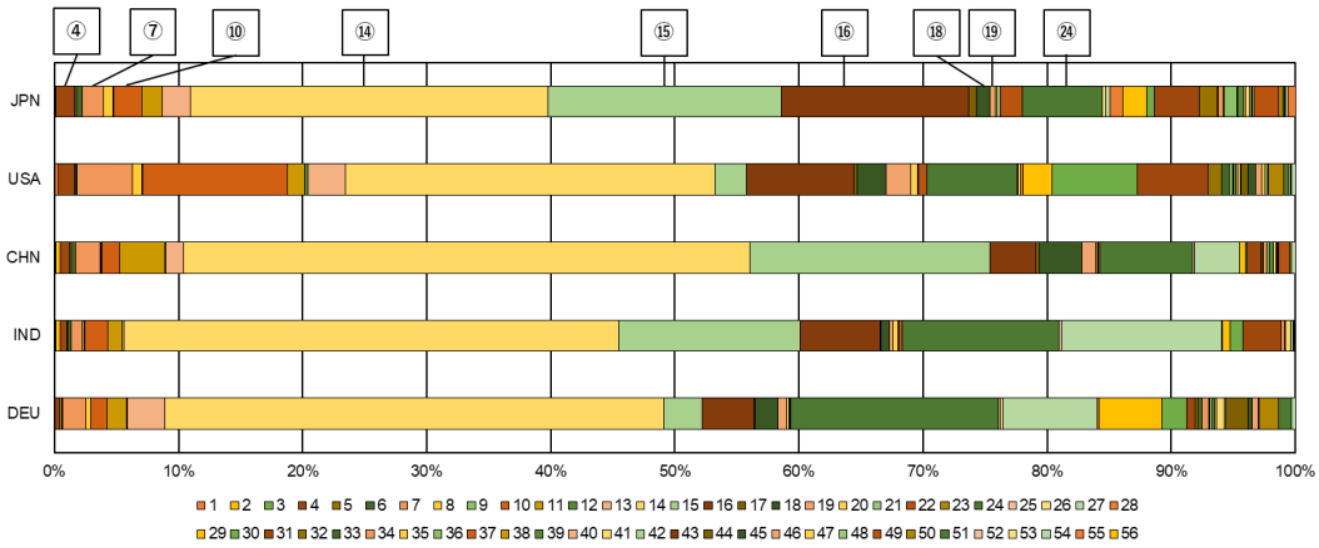

Figure 7. $\mathrm{CO}_{2}$ emissions by sectors comprising construction EGs.

The sectoral linkages on the construction sector can be evaluated by the traditional method of analyzing the column elements of the Leontief inverse matrix. In addition, a method called hypothetical extraction method (HEM) [17] is used. This is a method to evaluate the sectoral linkages by comparing the state with and without the target sector. However, in this study, since the $\mathrm{CO}_{2}$ emission intensity for each industrial sector was calculated in Section 3.2, the $\mathrm{CO}_{2}$ emissions of the sectors that contribute the construction EG can be calculated by multiplying the amount of sector that that is put into the construction sector by the intensity. This method is equivalent to the traditional method of analyzing the column elements of the Leontief inverse matrix.

According to Figure 7, sectors 14, 15, 16, and 24 are large contributors. These are the sectors that manufacture "cement", "steel bars and steel frames", and "energy sources". The proportion of $\mathrm{CO}_{2}$ emissions from these three materials accounts for around $60-80 \%$ of the construction EGs in each country.

Considering each construction-related material, "cement" tends to have a high ratio of $\mathrm{CO}_{2}$ emissions by sector in all countries, particularly in China and Germany, where it exceeds $40 \%$. In addition, "steel bars and steel frames" tend to have high contributions in Japan, India, and China, especially in the former, where they exceed 30\%. "Energy sources" tend to have high contributions in India, the United States, and Germany, especially in the latter pair, where they account for nearly $20 \%$.

In all countries, $\mathrm{CO}_{2}$ emissions in cement production, steel production, and energy supply were found to have a significant impact on construction EGs. Thus, it is very important to advance technological development to reduce $\mathrm{CO}_{2}$ emissions within these sectors.

\subsection{Relationship with Cement Production}

In the previous section, the sector of cement production was identified as having a large impact on construction EG. Figure 8 shows the relationship between $\mathrm{CO}_{2}$ emissions by cement production and construction EG in each country, according to statistical data on carbon emissions from the Carbon Dioxide Information Analysis Center (CDIAC) [18].

From Figure 8, since the approximate curve is an upward-sloping equation, a strong positive correlation between cement production and construction EGs was considered. It was found that $\mathrm{CO}_{2}$ emissions from cement production account for approximately $31 \%$ of construction EG in many countries. 


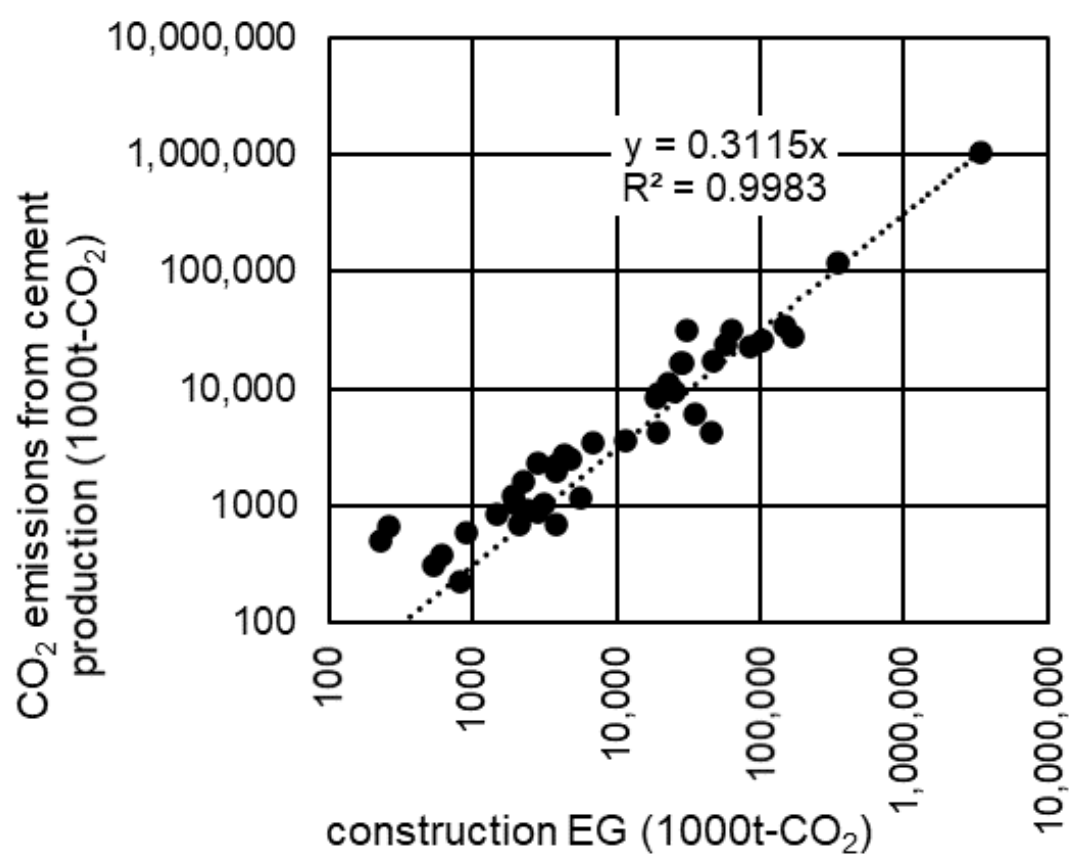

Figure 8. $\mathrm{CO}_{2}$ emissions from cement production and construction EGs.

\subsection{Annual Variation of Construction EGs}

Figure 9 shows the relationship between total $\mathrm{CO}_{2}$ emissions from 2000 to 2014 and construction EGs, and cement production in Japan, the United States, China, India, and Germany.

Total $\mathrm{CO}_{2}$ emissions in Japan have not changed significantly, with the lowest value recorded in 2009. Construction EGs were on a downward trend until 2011, with no significant changes recorded since 2011. $\mathrm{CO}_{2}$ emissions from cement production have not changed significantly.

Total $\mathrm{CO}_{2}$ emissions in the United States were on a downward trend until 2009, with no significant changes recorded since 2010, but a slight upward trend has been observed since 2013. Construction EGs were on a downward trend until 2012, but they have been on an increasing trend since 2012. $\mathrm{CO}_{2}$ emissions from cement production also showed almost the same tendency as construction EGs.

Total $\mathrm{CO}_{2}$ emissions in China have been on the rise, being 2.9 times higher in 2014 than in 2000. Similarly, construction EGs and $\mathrm{CO}_{2}$ emissions from cement production have also increased significantly (4.7 times and 4.2 times, respectively).

Total $\mathrm{CO}_{2}$ emissions in India have been on the rise, being 2.2 times higher in 2014 than in 2000. Construction EGs and $\mathrm{CO}_{2}$ emissions from cement production have also increased (2.4 times and 2.9 times, respectively).

Total $\mathrm{CO}_{2}$ emissions in Germany have been on a downward trend. Construction EGs were on a downward trend until 2005; however, since 2006, no major fluctuations have been observed, and a similar trend can be seen in $\mathrm{CO}_{2}$ emissions from cement production.

In China and India, total $\mathrm{CO}_{2}$ emissions, construction EGs, and $\mathrm{CO}_{2}$ emissions from cement production have all increased. This was due to increased investment in the construction sector. This is considered to be a characteristic of developing countries. On the other hand, in Japan, the United States, and Germany, total $\mathrm{CO}_{2}$ emissions and construction EGs have decreased. However, in recent years, there has been no significant change in construction EGs and $\mathrm{CO}_{2}$ emissions from cement production. This is considered to be a characteristic of developed countries.

There was a clear trend for developing countries (India and China). By contrast, for developed countries (the United States, Japan, and Germany), the trend was not so clear. 


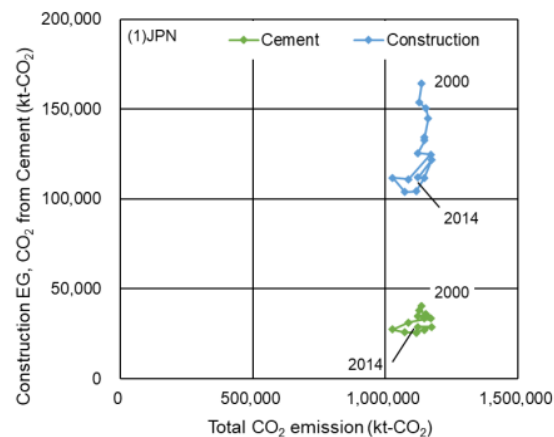

(a) JPN

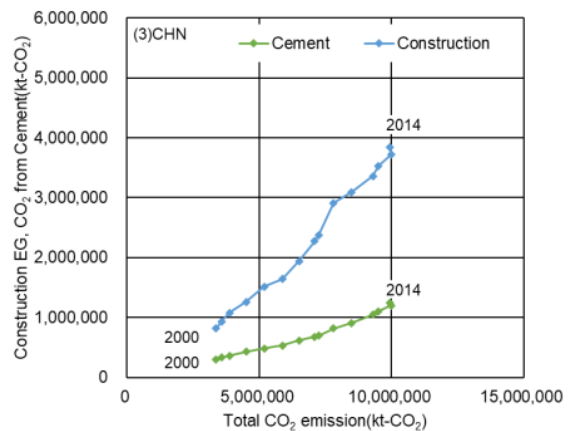

(c) $\mathrm{CHN}$

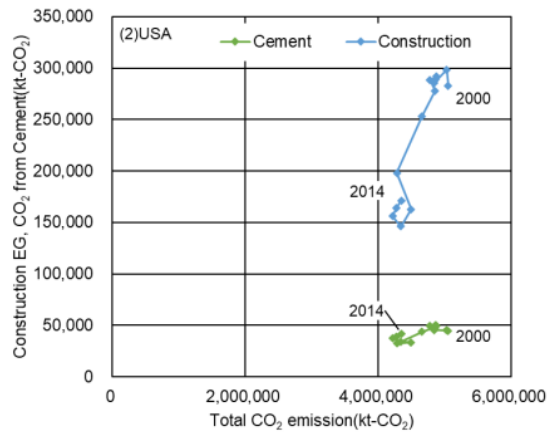

(b) USA

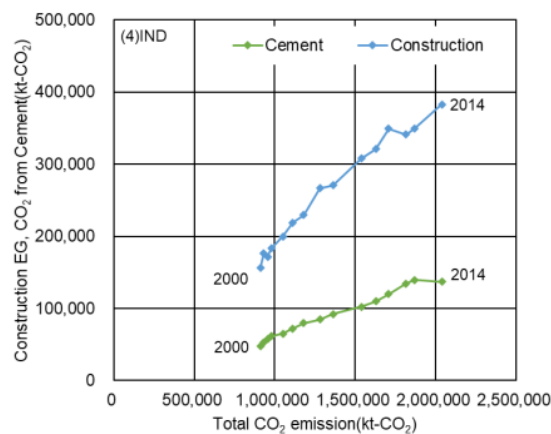

(d) IND

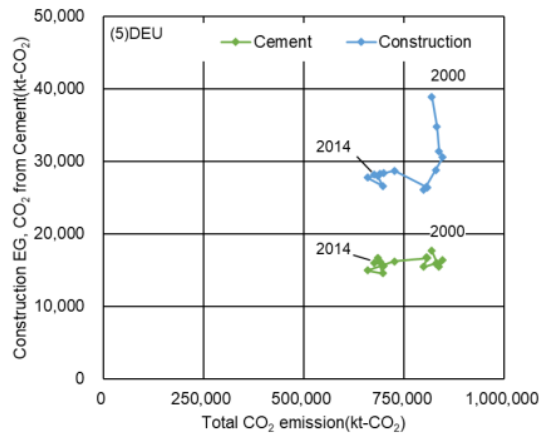

(e) DEU

Figure 9. Annual variations in total $\mathrm{CO}_{2}$ emissions, construction $\mathrm{EGs}$, and $\mathrm{CO}_{2}$ emissions from cement production.

Figure 10 shows the annual variation in the fraction of construction EG. Compared to India, China has the largest fraction of construction EG demonstrating a strong increasing trend. On the other hand, India changed from 17\% (2000) to 19\% (2014), with only a slight increase. In both cases, construction EGs have increased, which is a characteristic of developing countries, but it can also be seen that there was a clear difference in the increasing trend.

Germany has remained at around 4\%, while the United States has remained at around $5 \%$. Among the five countries, Germany and the United States are characterized by a low fraction of construction EG and small fluctuations. However, the fraction of construction EG in Japan has been intermediate among the five countries, showing a gradual downward trend from $14 \%$ (2000) to $10 \%$ (2014). 


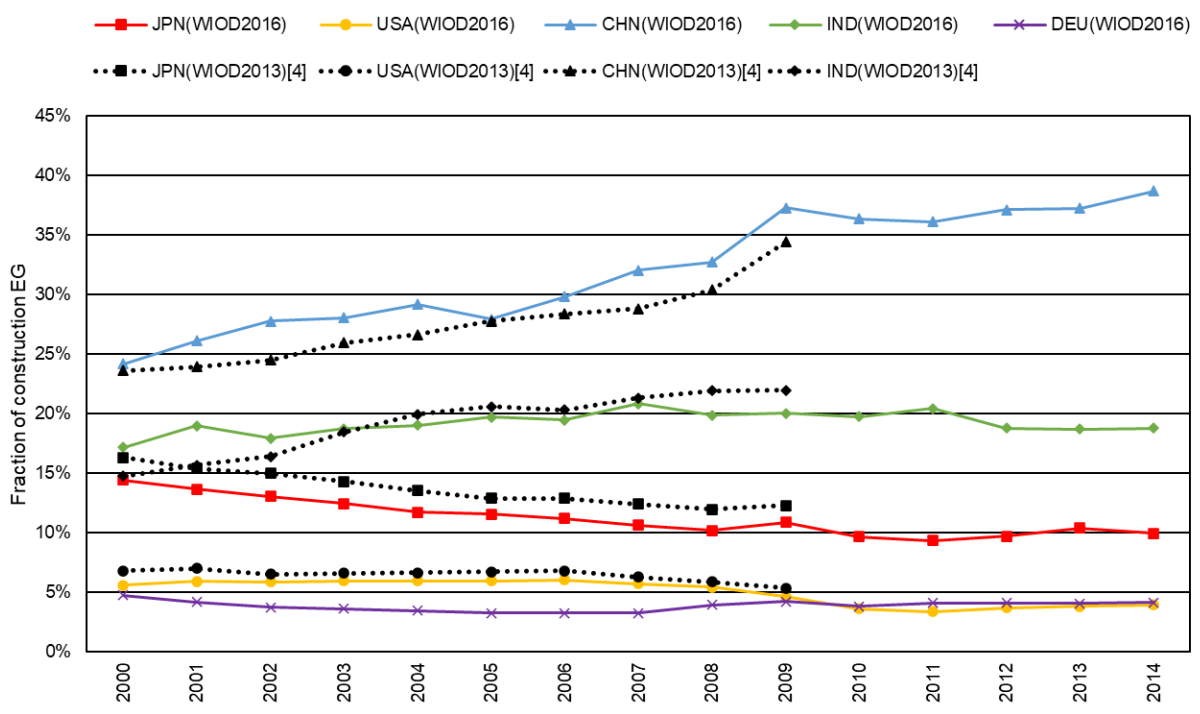

Figure 10. Annual variations in fraction of construction EGs. The fraction of construction EG of WIOD (2013) is cited from Reference [4].

From the above, it can be noted that the fraction of construction EG in developing countries is large and rising, whereas it is small and stable in developed countries.

Compared with the 2013 analysis results [4], the construction EG values from 2000 to 2009 are slightly different; however, their trends are almost the same.

\section{Discussion}

This study aimed to clarify the characteristic of construction EG as a material for formulating policies for reducing emissions in each country.

In this study, the construction EGs of 43 countries from 2011 were analyzed. The 56-sector input/output table and $\mathrm{CO}_{2}$ emission data of the 2016 World Input/Output Database, published by the EU were used in this analysis. The $\mathrm{CO}_{2}$ emissions intensities in 56 sectors in 43 countries were obtained.

The total $\mathrm{CO}_{2}$ emissions of the 43 countries included in this analysis account for about $80 \%$ of the world's total energy-derived $\mathrm{CO}_{2}$ emissions. In addition, the sector with the highest share of total $\mathrm{CO}_{2}$ emissions in the 43 countries was "27: construction", which was shown to be the highest in the following order of countries: China, India, Russia, the United States, and Japan.

It was found that developing countries tend to have higher construction EGs. The large fraction of construction EG in developing countries is thought to be due to the construction of many facilities such as buildings, roads, and railroads for economic development. Therefore, it is important to promote methods for reducing construction EGs.

$\mathrm{CO}_{2}$ emissions by construction sectors in Japan, the United States, China, India, and Germany were analyzed. As a result of this analysis, the sectors manufacturing "cement", "steel bars and steel frames", and "energy sources" were found to be large contributors, and the fraction of $\mathrm{CO}_{2}$ emissions by these three sources is around $60-80 \%$ of the construction EGs in the five countries.

In addition, annual variation from 2000 to 2014 in total $\mathrm{CO}_{2}$ emissions, construction EGs, $\mathrm{CO}_{2}$ emissions from cement production in five countries as above were compared. In China and India, total $\mathrm{CO}_{2}$ emissions, construction EGs, and $\mathrm{CO}_{2}$ emissions of cement production have all increased, which could be due to a sharp increase in investment in the construction sector. This is a characteristic of developing countries. On the other hand, in Japan, the United States, and Germany, total $\mathrm{CO}_{2}$ emissions, construction EGs, and $\mathrm{CO}_{2}$ emissions from cement production have been on a downward trend; however, in recent years, there has been no significant change in construction EGs and $\mathrm{CO}_{2}$ emissions from cement production. This is considered to be a characteristic of developed countries. The 
fraction of construction EG was around 4\% each year in Germany and around 5\% each year in the United States, both of which show a flat trend. The fraction of construction EG in Japan was intermediate among the five countries, showing a gradual downward trend.

Compared with the WIOD (2013) analysis results [4], it was confirmed that the construction EG values were slightly different, but the trends were similar to those mentioned above.

$\mathrm{CO}_{2}$ emissions from cement production, steel production, and energy supply heavily affect construction EG. Therefore, measures to reduce these $\mathrm{CO}_{2}$ emissions are important in terms of reducing construction EGs. Construction EGs in developing countries are expected to continue increasing in the future; therefore, countermeasures are urgently needed. To shrink carbon emissions, resource-recycling manufacturing methods should be considered. These could include cement production without $\mathrm{CO}_{2}$ emissions, recycling cement from used concrete, and the utilization of renewable energy. All of these are effective as countermeasures. Furthermore, in addition to the efforts of each country, it is desirable for developed countries to provide their proven $\mathrm{CO}_{2}$ emission reduction technologies to developing countries.

Author Contributions: Conceptualization, Y.M. and K.Y.; Methodology, Y.M., Y.S. and K.Y.; Formal analysis, Y.M. and Y.S.; Data curation, Y.M. and Y.S.; Writing —original draft preparation, Y.M.; Writing-review and editing, K.Y.; Visualization, Y.M. and Y.S.; All authors have read and agreed to the published version of the manuscript.

Funding: This research received no external funding.

Conflicts of Interest: The authors declare no conflict of interest.

\section{Nomenclature}

\begin{tabular}{|c|c|}
\hline \multicolumn{2}{|l|}{ Abbreviatior } \\
\hline ZEBs & net-zero-energy buildings \\
\hline ZEHs & net-zero-energy houses \\
\hline EU & European Union \\
\hline GNI & Gross National Product \\
\hline GHG & greenhouse gas \\
\hline $\mathrm{EE}$ & embodied energy \\
\hline EGs & embodied GHG emissions \\
\hline EEGs & embodied energy and GHG emissions \\
\hline WIOD & World Input-Output Database \\
\hline IEA & International Energy Agency \\
\hline EBC & Energy in Building and Communities \\
\hline PEf & primary energy from fossil fuels only \\
\hline PEnr & primary energy from fossil fuels and nuclear power \\
\hline PEt & total primary energy from fossil fuels, nuclear power, and renewable energy \\
\hline WIOT & world IO table \\
\hline NIOT & national IO tables \\
\hline USD & US dollars \\
\hline \multicolumn{2}{|l|}{ Symbols } \\
\hline $\mathrm{a}_{\mathrm{ij}}^{\mathrm{d}}$ & the input coefficient for domestic goods \\
\hline$X_{i j}^{d}$ & the domestic product from sector $\mathrm{j}$ to sector $\mathrm{i}$, million USD/year \\
\hline$X_{i}^{\prime}$ & the gross domestic product (total output), million USD/year \\
\hline$x$ & the gross domestic product vector, million USD/year \\
\hline$\left(I-A^{d}\right)^{-1}$ & the Leontief inverse matrix \\
\hline I & the unit matrix \\
\hline$A^{d}$ & the activity matrix of the gross domestic product with $\mathrm{a}_{\mathrm{ij}}^{\mathrm{d}}$ as an element \\
\hline $\mathrm{F}^{\mathrm{d}}$ & the final demand vector of domestic goods, million USD/year \\
\hline $\mathrm{F}^{\mathrm{E}}$ & the export vector, million USD/year \\
\hline $\mathrm{ICO}_{2}$ & $\begin{array}{l}\text { the } \mathrm{CO}_{2} \text { emission basic unit vector with spillover effects per manufacturer price } \\
\text { of } 1 \text { million USD in each industry, } \mathrm{kg}-\mathrm{CO}_{2} / \text { million USD }\end{array}$ \\
\hline
\end{tabular}




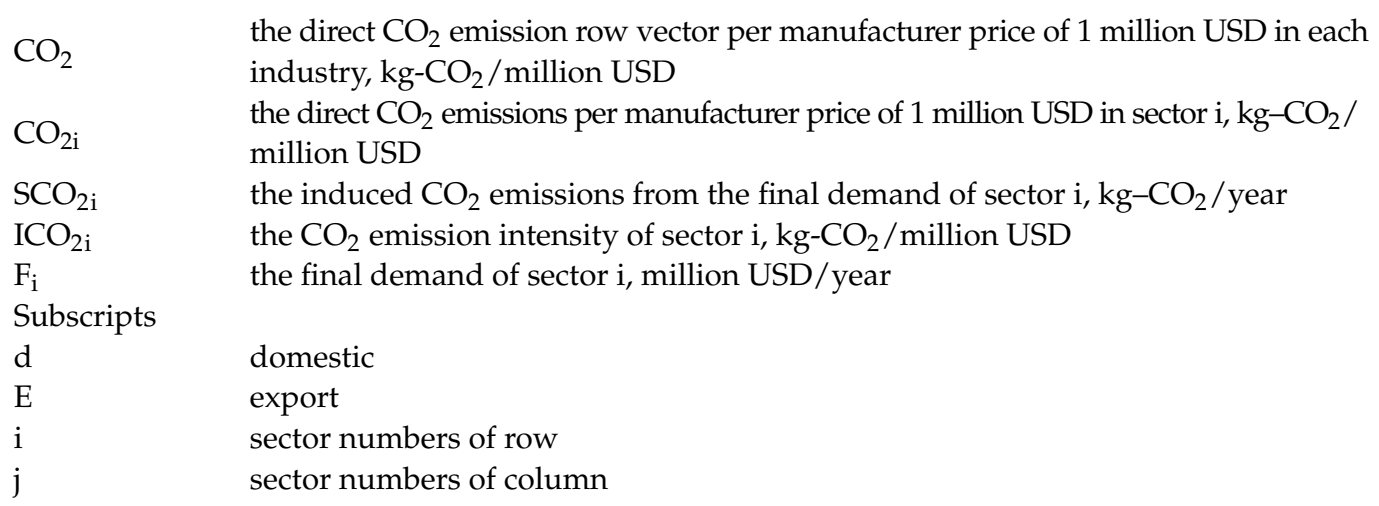

\section{References}

1. Ministry of Foreign Affairs of Japan, Paris Agreement. Available online: https://www.mofa.go.jp/mofaj/files/000197313.pdf (accessed on 8 April 2021).

2. Birgisdottir, H.; Moncaster, M.; Wiberg, A.H.; Chae, C.; Yokoyama, K.; Balouktsi, M.; Seo, S.; Oka, T.; Lützkendorf, T.; Malmqvist, T. IEA EBC annex 57 'evaluation of embodied energy and CO2eq for building construction'. Energy Build. 2017, 154, 72-80. [CrossRef]

3. Timmer, M.P.; Dietzenbacher, E.; Los, B.; Stehrer, R.; de Vries, G.J. An Illustrated User Guide to the World Input-Output Database: The Case of Global Automotive Production. Rev. Int. Econ. 2015, 23, 575-605. [CrossRef]

4. Yokoyama, K. Study on worldwide embodied impacts of construction. J. Environ. Eng. 2021, 779, 101-109. (In Japanese) [CrossRef]

5. IEA EBC Annex57. Available online: http:/ / www.annex57.org/ (accessed on 7 July 2018).

6. Cruz, L.; Dias, J. Energy and $\mathrm{CO}_{2}$ intensity changes in the EU-27: Decomposition into explanatory effects. Sustain. Cities Soc. 2016, 26, 486-495. [CrossRef]

7. Zhang, Z.; Xi, L.; Bin, S.; Yuhuan, Z.; Song, W.; Ya, L.; Hao, L.; Yongfeng, Z.; Ashfaq, A.; Guang, S. Energy, CO 2 emissions, and value added flows embodied in the international trade of the BRICS group: A comprehensive assessment. Renew. Sustain. Energy Rev. 2019, 116, 109432. [CrossRef]

8. Magnus, J.; Viktoras, K.; Astrid, K. Consumption versus Technology Drivers of Global Carbon Emissions 2000-2014. Energies 2020, 13, 339.

9. Fan, J.-L.; Hou, Y.-B.; Wang, Q.; Wang, C.; Wei, Y.-M. Exploring the characteristics of production-based and consumption-based carbon emissions of major economies: A multiple-dimension comparison. Appl. Energy 2016, 184, 790-799. [CrossRef]

10. Zhang, L.; Liu, B.; Du, J.; Liu, C.; Wang, S. Energy, $\mathrm{CO}_{2}$ emission linkage analysis in global construction sectors: Alarming trends from 1995 to 2009 and possible repercussions. Renew Sustain. Energy Rev. 2019, 221, 863-877.

11. Corsatea, T.D.; Lindner, S.; Arto, I.; Román, M.V.; Rueda-Cantuche, J.M.; Velázquez Afonso, A.; Amores, A.F.; Neuwahl, F. World Input-Output Database Environmental Accounts. In Update 2000-2016; Publications Office of the European Union: Luxembourg, 2019; JRC116234; ISBN 978-92-79-64439-9. [CrossRef]

12. WORLD BANK, GNI (Current US\$) Data, Last Updated Date 1 July 2020. Available online: https://data.worldbank.org/ indicator/NY.GNP.MKTP.CD (accessed on 6 September 2020).

13. WORLD BANK, Population, Total Data, Last Updated Date 1 July 2020. Available online: https:/ / data.worldbank.org/indicator/ SP.POP.TOTL (accessed on 6 September 2020).

14. IEA, $\mathrm{CO}_{2}$ Emissions from Fuel Combustion. 2019. Available online: https://www.iea.org/subscribe-to-data-services/co2 -emissions-statistics (accessed on 18 April 2020).

15. Ministry of Internal Affairs and Communications Japan, 2011 Input-Output Tables for Japan. 2016. Available online: https: / / www.soumu.go.jp/main_content/000443188.pdf (accessed on 10 May 2021).

16. WORLD BANK, Newest Country Classifications Released. 2012. Available online: https://blogs.worldbank.org/opendata/ newest-country-classifications-released (accessed on 8 April 2021).

17. Erik, D.; Van Der Linden, J.A. Sectoral and spatial linkages in the EC production structure. J. Reg. Sci. 1997, 37, $235-257$.

18. National $\mathrm{CO}_{2}$ Emissions from Fossil-Fuel Burning, Cement Manufacture, and Gas Flaring, 1751-2014. 2017. Available online: https:/ / cdiac.ess-dive.lbl.gov/ftp/ndp030/nation.1751_2014.ems (accessed on 8 April 2021). 